\title{
Analysis of conditions and the concept of multidirectional revitalization of the dolomite quarry in Siewierz
}

\author{
Katarzyna Pawełczyk ${ }^{1, *}$ \\ ${ }^{1}$ AGH University of Science and Technology, Faculty of Mining and Geoengineering, Department \\ of Surface Mining, 30 A. Mickiewicz Av., 30-059 Kraków, Poland
}

\begin{abstract}
The development of mining of rock raw materials in Poland has significantly contributed to economic growth and the quality of life of local communities. However, mining activity, besides a number of positive effects, also implies broadly understood changes in the environment and the formation of brownfields. Reclamation and redevelopment of postindustrial areas, and especially post-mining areas, is currently a huge environmental and socio-economic challenge. Revitalization of postmining areas is particularly important for small towns and municipalities, where mining was one of the main pillars of development and prosperity. An example of such a municipality is Siewierz in Silesian Voivodship. In the paper analysis the conditions have been conducted and the concept of revitalization of dolomite quarry Górnicze Zakłady Dolomitowe S.A. has been proposed. The AHP method has been used to analyse and select the optimal method of revitalization. As a result of the analysis, the concept of multidirectional revitalization with socially, economically and environmentally beneficial functions has been created, maximizing the potential of the quarry.
\end{abstract}

\section{Introduction}

Development of mining industry which could have been observed in the previous century, undoubtedly contributed to economic growth so from economic point of view was very beneficial and desired phenomena. Opening of new mine gave not only the possibility of gaining valuable raw materials, but also provided new work places and, what goes with it, raising living conditions and financial situation of local community. It concerns especially small towns, where deposits of natural minerals were a huge potential for growth. However, it is worth remembering that with widely understood social-economic growth of areas where mining activity took place, degradation of natural environment progressed. Negative influence of extraction of minerals appears through many phenomena, occurring in different environmental components.

Reclamation, through entering it into law making ceased to be treated as additional activity, going beyond entrepreneur's responsibility. Nowadays it is one of the steps of

\footnotetext{
*Corresponding author: pawelczyk@agh.edu.pl
} 
mining activity and according to the bill from $9^{\text {th }}$ of June 2011 Geological and Mining law to its realization rules of the bill from $3^{\text {rd }}$ of February 1995 about protection of agricultural and forest lands are applied. Moreover, suitable and thought-through development of postmining area may significantly raise its attractiveness, at the same time improving the image of mining in the society [1]. Because of the scale of interference into natural environment, the process of revitalization is long, complex and demands introduction of many interdisciplinary analysis. However, it is worth underlining that thorough analysis of conditioning and coming to correct conclusions, and consequently formation of suitable concept of redevelopment, gives huge possibilities of creating new role of the area which attractiveness may reach far beyond local community [2].

Revitalization of post mining areas is extremely significant It is unacceptable to leave areas degraded as a result of exploitation without giving them new, useful, from the local communities point of view, functions which will allow for effective use of the potential to build a new land value according to rules of sustainable development. It's worth being mindful of that a mine may be a huge chance for development for the community, not only during undergoing extractive activity but also after its end. Perfect example of it may be brown coal mine "Konin", the ground of which has higher soil quality class after performing reclamation than before taking it over for mining purposes [2], reclamated sulphur mine „Machów”, excavation of which was turned into water reservoir Tarnobrzeskie Lake very popular and liked by local community or finally hard coal mine „Kleofas” in Katowice, on place of which commercial center Silesia City Center was created - its design, architecture and incorporation of mine elements refers to mining tradition of the region.

\section{Subject and aim of the papers}

The subject of this paper is the quarry of Triassic and Devonian dolomite exploited by Górnicze Zakłady Dolomitowe S.A. located in Siewierz in Silesian Voivodship. The aim of the paper is to choose optimal reclamation direction of the mine as well as working out the concept of target redevelopment of the area based on all relevant factors that have been analyzed.

\section{Research method}

In order to determine optimal way of reclamation and redevelopment of the quarry of Triassic and Devonian dolomite exploited by Górnicze Zakłady Dolomitowe S.A. following elements of post exploration area development design method were applied [3]:

- $\quad$ systematization of factors and criteria which have an influence on the choice of the direction of reclamation and their analysis;

- determination main and complementary functions for particular parts of the area based on factor analysis;

- hierarchization of factors and the choice of optimal concept of area's redevelopment;

- $\quad$ establish of rules of realization of chosen concept and functioning of revitalized area.

The choice of optimal direction of revitalization is based on selected elements of AHP method, i.e. analytic hierarchy process. Postulates of the method is simplification of decision-making process in case when the choice must be done based on many criteria and with the help of immeasurable parameters. It makes difficult and complex problems come down to sequences of paired comparison [3] as it is shown on figure 1. In the case of this 
article, all factors have been compared in pairs, then as a result of this comparison, the most important factors have been identified and their hierarchy has been created. The next step was to compare the previously created concepts of revitalization (based on a detailed analysis of factors) with respect to the most important factors and selection a concept that would meet the criteria resulting from the adopted hierarchy in the highest degree.

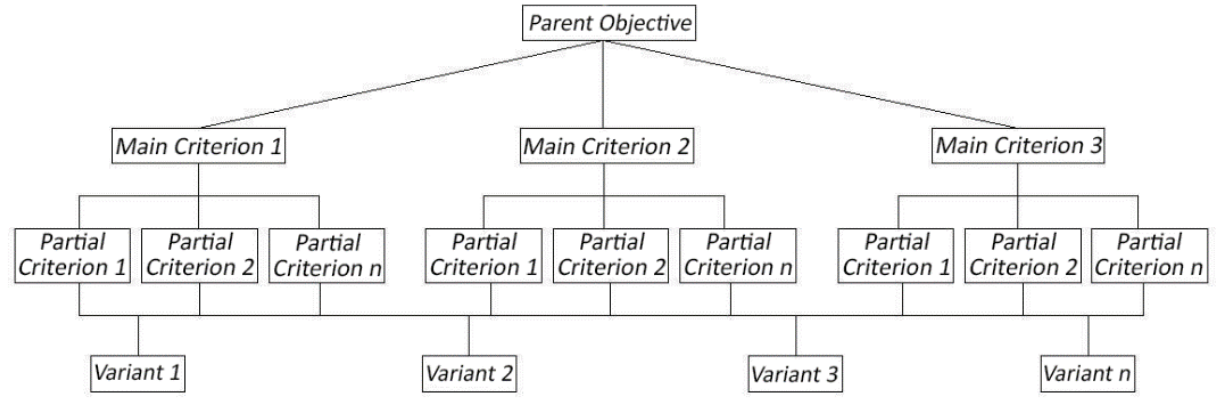

Fig. 1. Diagram of general hierarchic structure [3].

\section{Analysis of conditions}

In this chapter characteristics of the quarry of dolomite in Siwierz has been discussed on the base of documentation provided by the Górnicze Zakłady Dolomitowe S.A. as well as onsite inspection.

\subsection{Spatial factors}

The quarry of dolomite Zakłady Dolomitowe S.A.is located in the north end of Siewierz in Silesian Voivodship, about 35 kilometers east-north of Katowice and about 40 kilometers south of Częstochowa. Significant spatial factor is location of the mine in the external zone of upper Silesian conurbation, which makes polycentric settlement form, consociating 54 boroughs, including 2 boroughs of Lesser Poland Voivodship. Siewierz borough borders also with Silesian Metropolis [4]. The quarry is located directly by the express road E75 of international status connecting Cieszyn and Gdańsk. Other significant communication routes are located nearby as well. Such as highway A1 (Pyrzowice - Gorzyczki), trunk road 78 (Chałupki - Chmielnik), trunk road 86 (Podwarpie - Tychy) or trunk road 94 (Zgorzelec - Korczowa), connecting west with east of the country. Many communication routes in the nearest neighborhood of the mine makes it easy to get there not only from Silesian area, but also from all over the country. Moreover, public transport stops are located nearby.

The nearest surroundings of the mine are:

- $\quad$ on the north - wasteland area with buildings of Dziewki village;

- on the east - wasteland, industrial areas and the village of Kazimierzówka with dense residential buildings and singular orchards;

- $\quad$ on the south - wasteland areas, meadows and forests;

- $\quad$ on the west - wasteland areas, behind which there is express road E75 and further buildings of Brudzowice village [5]

Layout of neighboring villages may be described as linear settlement with housing on each side of local roads, therefore the area isn't high-densely housed and significant part of it consists of agricultural wasteland and small forests. Area located around the mine was shown on ortophotomap in the figure 2. 


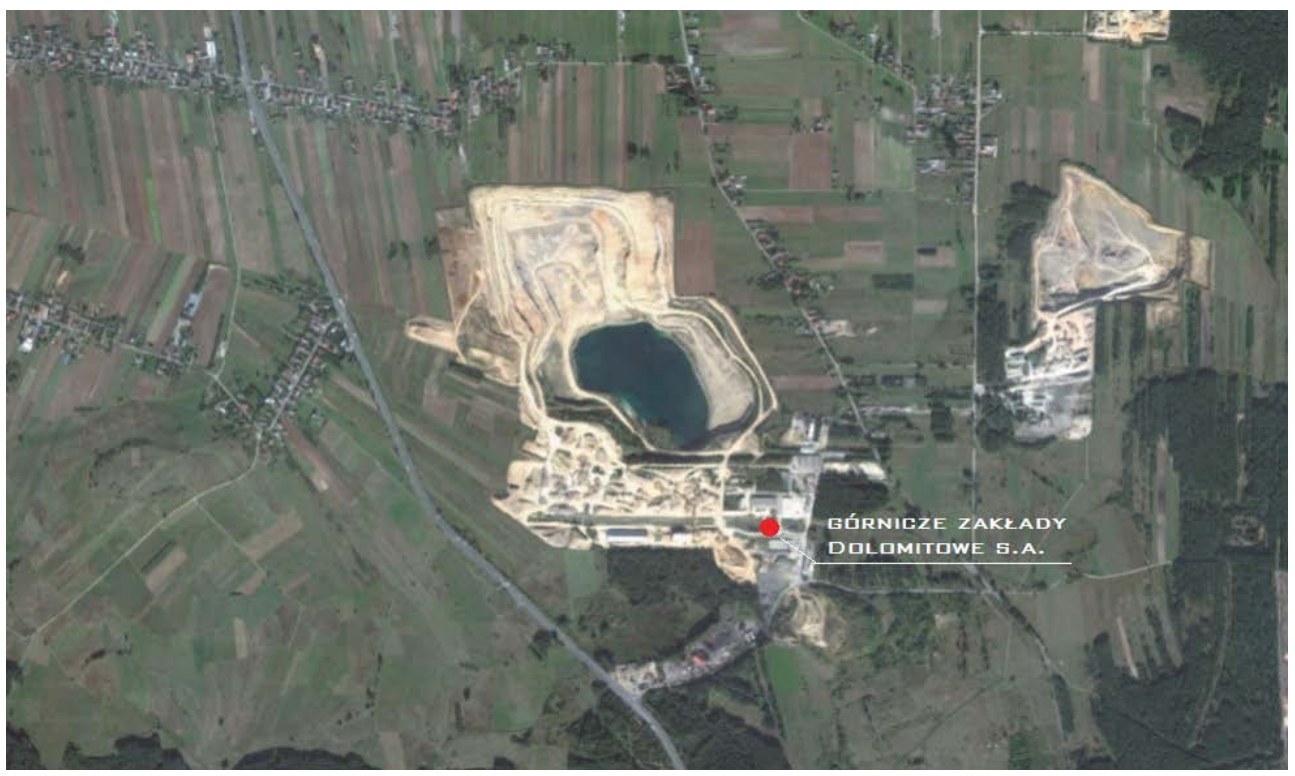

Fig. 2. The surroundings of the dolomite mine. Source: https://www.google.pl/maps.

\subsection{Geological-engineering factors}

Geological conditions were characterized on the base of geological documentation of dolomite deposit "Brudzowice" [6]. Dominant formations in geology of the area are Devonian, Triassic and Quaternary formations. Deposit is located on the north-east outskirts of Upper Silesian Coal Basin within anticline Dziewki-Brudzowice. A part of the deposit, including Devonian dolomites is located in central part of tectonic edge, forming erosive hill characteristic of uneven surface and steep slopes. South and north part of the hill develops into abrasion platform with gradual slopes.

Devonian dolomites are developed in the form of collarian carbonate layout, which is characteristic of grey, dark grey and violent color, crystallinity and huge hardness. The Triassic on the described area is represented by motley sandstone, conchoidal limestone and keupers. The overburden is built of quaternary formations, which consist of: soil, sands and rock waste clay contains dolomite crumbs. Thickness of the layer is about 5 meters. Exploitation is done in mine working on seven levels, beginning from +340 meters above sea level and ending on +280 meters above sea level. The lowest level is flooded with water.

Exploitation is done by wall system on following levels in east, west and north direction. At a distance of $6 \mathrm{~m}$ from the border of the plot, a protective shaft is formed from the overburden removed. The surface of the excavation is about 88,7 ha and average depth is around $65 \mathrm{~m} \mathrm{[5].} \mathrm{Current} \mathrm{development} \mathrm{of} \mathrm{the} \mathrm{mine} \mathrm{divides} \mathrm{its} \mathrm{area} \mathrm{into} \mathrm{four} \mathrm{parts.} \mathrm{The}$ first of them is partially flooded excavation with technological roads, the second is external dump, the third is processing plant together with raw material and processed products warehouses and the fourth is administration buildings with the board of Górnicze Zakłady Dolomitowe S.A. 


\subsection{Hydrological factors}

The quarry is located in catchment of Vistula river between two rivers - Czarna Przemsza and Brynica. The northern part of the mining area is a watershed for the rivers. Described area is poor in surface natural watercourses. In the nearest neighborhood of the mine there is Jordan stream which is right tributary of Czarna Przemsza. The stream is about 800 meters north-east away from the mine and it is a place of draining water from mine dewatering [7].

In the direct neighborhood of the quarry there is no other aquatic reservoir. However, in $25 \mathrm{~km}$ radius there are other big reservoirs of recreational and economic character, among others: Pogoria I, Pogoria II, Pogoria III i Pogoria IV, which are post exploitation excavations of sand mines. According to the division of the National Hydrogeological Service of the Polish territory into groundwater bodies (JCWPd), the area is located in the Central Vistula Subregion, ie JCWPd No. 112. The quarry is located in the northern part of the Main Underground Water Reservoir No. 454 Olkusz - Zawiercie and in the southern part part of the Main Underground Water Reservoir No. 337 Lubliniec - Myszków. Average depths of water intakes in the areas of reservoirs range from $100 \mathrm{~m}$ to $135 \mathrm{~m}$. However, the average depth of groundwater deposition in the mining area varies within about $2 \mathrm{~m}$ in the southern part to about $10 \mathrm{~m}$ in the northern part of the area [7]. Currently dewatering is performed up to +280 meters above the sea level.

\subsection{Formal-law factors}

The area being the subject of the study is covered by both the study of conditions and directions of spatial development as well as the local spatial development plan for the mining area. Those documents imply the direction and way of developing the lands on which the mine is located. The study of conditions and directions of spatial development of the town and borough of Siewierz determines water direction of excavation reclamation. However, areas adjacent to the excavation located in the Górnicze Zakłady Dolomitowe are destined to afforestation. The area where the buildings are located are designed for commercial and production activity [8].

Local spatial development plan for mining area predicts water direction of target redevelopment of the excavation. For the dumps forest reclamation direction is decided. The buildings, roads and squares could be used for economic purposes. Created reservoir is to have a role of storage reservoir without a possibility to use it for recreational purposes. The ground mass is to be used for formation of target land form. Moreover, isolating green zones were designed as well as open spaces destined for meadows, pastures and crops [9].

The area of the quarry is not under any form of environmental protection in the understanding of the bill from $16^{\text {th }}$ of April 004 about environmental protection (tekst jedn. z 2016 r. Dz.U. z 2015 poz. 1651) and it does not belong to European ecological net Nature 2000. On the area of the mine there is no monumental objects included in the Registry of Monuments of Silesia Voivodship.

\subsection{Environmental factors}

The mine is located on the lands greatly covered by forests, mainly coniferous forests. Moreover, in the river valleys there are ash-alder forests as well as currant alder and peaty alder forests. However, on the calcic base surface turfs are developed. Important element of natural world are also meadows [7]. On the south and north slopes of the excavation young trees such as: birch, spruce, pine and willow are located. Moreover, by the office and warehouse decorative species of shrubs and trees were introduced such as: hedgerows or 
larches. Surrounding of the mine consists of coniferous and birch tree stand, crop fields and wastelands of meadow character.

Fauna and flora on the quarry area is very poor because of the opencast dolomite exploitation. The nearest surrounding of the quarry has anthropogenic character as well because of communication infrastructure and housing. Current development of the area makes it quite difficult to create suitable conditions for animal habitat. The significant part of soil in the mine area was extracted because of making deposit available and building technical infrastructure necessary for functioning of the mine. Extracted soil is stored in the form of protection banks, giving a possibility of using it again during the reclamation process.

In order to protect stored soil and soil located around the mine much work is performed if comes to suitable waste and wastewater management as well as taking care of technical state of machines and devices so as to mineralized their negative influence on the environment [7].

\subsection{Cultural-historical factors}

Siewierz borough is one of the oldest settlement in Poland and has very rich history. Someday it was a capital of principality and developed trade and industry center located on the crossroad of many significant trade routes. Buyers traditions reach Middle Ages times. There are many historical and cultural heritage objects in the town such as for example: The Castle of Silesian Princes, the main square, chapels and sacral objects. All those monuments are located at least 3 kilometers away from the mine [10].

All devices, machines and buildings on the mining area cannot be qualified as monuments even in common undertaking of this word because of relatively young age. Nevertheless because of direct neighborhood of Upper Silesia, where mining culture and tradition are strongly developed and rooted, all material goods connected with mining are perfectly written into industrial heritage of the region.

Historical character of the borough and great number of objects of recreational-cultural character creates a question about the point of creating another area of high touristic potential. It is worth remembering though that because of long exploitation period - the mine started its activity in 1954, this area is characterized by mining identity, which is worth underlining and cultivating.

\subsection{Social factors}

Demographic structure on the studied area is very varied. According to date of GUS from 2014 [11], 12284 people lived in the area of town-village borough Siewierz. Women are the majority among residents. The level of unemployment is lower than in the county. Especially the employment of women is on much better level according to statistics from 2015 , what may be connected with majority of services in the local market and small part of industry in the borough's economy. Economy of Siewierz is in much better position comparing to neighboring boroughs [8].

Because of village-town character of the borough, various social needs need to be taken into consideration. Expectations of Siewierz town residents will be different to nearby villages residents. The quarry is located on the outskirts of the town in the direct neighborhood of Brudzowice and Dziewki village, residents of which are employed in the mine. Agricultural activity decreases year by year, therefore for this social group it is greatly important and essential to keep and create new work places. The possibility of undertaking work in small distance from the place of residence is also beneficial, what is worth taking into consideration on the level of giving new function to post mining area. 


\subsection{Economic factors}

Economic factors play greatly significant role in the process of reclamation and revitalization. Mining entrepreneur is responsible for reclamation of the quarry according the law. Górnicze Zakłady Dolomitowe S.A. have a license for mineral exploitation given by the Minister of Environmental Protection, Natural Resources of Minister of Forestry. Therefore, according to the bill from 9th of June 2011 Geological and Mining Law (tekst jedn. z 2016 r. Dz.U. z 2015 poz. 196) have the duty to create Mine Liquidation Fund and gathering there the means designed for liquidation of the mine and reclamation of the grounds. Because of the water-retaining destination of the reservoir [5], protection and adjusting of banks and areas around the excavation will demand less work, and so less expense, than in the case of recreational use. Introduction of greenery will not demand brining special soil, because good quality soil which was taken off during making deposit available is storage by the excavation and is destined for reclamation purposes. This aspect also will decrease expenses necessary to perform the reclamation work.

New functions of the area should be designed in such way to make it possible that they will finance themselves. What is more, it is necessary to use significant potential in the form of facilities and buildings located in the borders of Górnicze Zakłady Dolomitowe S.A., which now are in good state. Their adaptation will cause decrease of reclamation costs, and may also bring potential private investors, since adaptation will be connected with lower costs than building new facilities.

\section{The choice of reclamation direction}

The analysis of particular factors influencing the choice of reclamation direction has shown preferences and restrictions concerning future redevelopment of the area. According to postulates of AHP methods the main aim is to work on the optimal concept of the reclamation of the dolomite quarry in Siewierz. Detailed analysis of all the factors makes possible multidirectional development of dolomite quarry emerge, such as:

- Option 1: Water direction - water-retaining for the excavation, forest-landscape for the areas around the excavation and didactic for area of processing facilities, warehouses and administration buildings.

- Option 2: Water direction - water-retaining for the excavation, forest-landscape for the areas around the excavation and business-service for the area of processing facilities, warehouses and administration buildings.

- Option 3: Water direction- water-retaining for the excavation, forest-landscape for the areas around the excavation and economic-industrial for the area of processing facilities, warehouses and administration buildings.

Optimal development of the lands of processing facilities, warehouses and administration buildings emerges at least three mentioned above possibilities. According to the AHP method after comparing all the factors in pairs done by the author, the most important factors (with the highest priority) based on previous analysis are decided to be: economic, formal-law, social and environmental. Local law acts forbid recreational use of reservoir and determine target destination of the lands located in the borders of Górnicze Zakłady Dolomitowe S.A. Water retaining redevelopment of excavation and afforestation of the surrounding areas comes from urban planning documents of the borough. Prohibition for recreational usage of the reservoir may be connected with high concentration of lakes located in nearby neighborhood of described area what is connected with the lack of the point of creating next place for recreational purposes. Moreover, there is already many recreational lands in Siewierz. Because of economic factors it is demanded to keep the investment profitable as it will allow to attract the investors and keep the investment. Good 
prospering of introduced investments relates directly to social factors by creating new work places. Obviously other factors must be also taken into consideration, such as for example environmental. Analysis of previously described options of development in the face of assumed hierarchy of factors deciding about optimal direction of revitalization leads to the choice of option 2 . The process was shown in the figure 3.

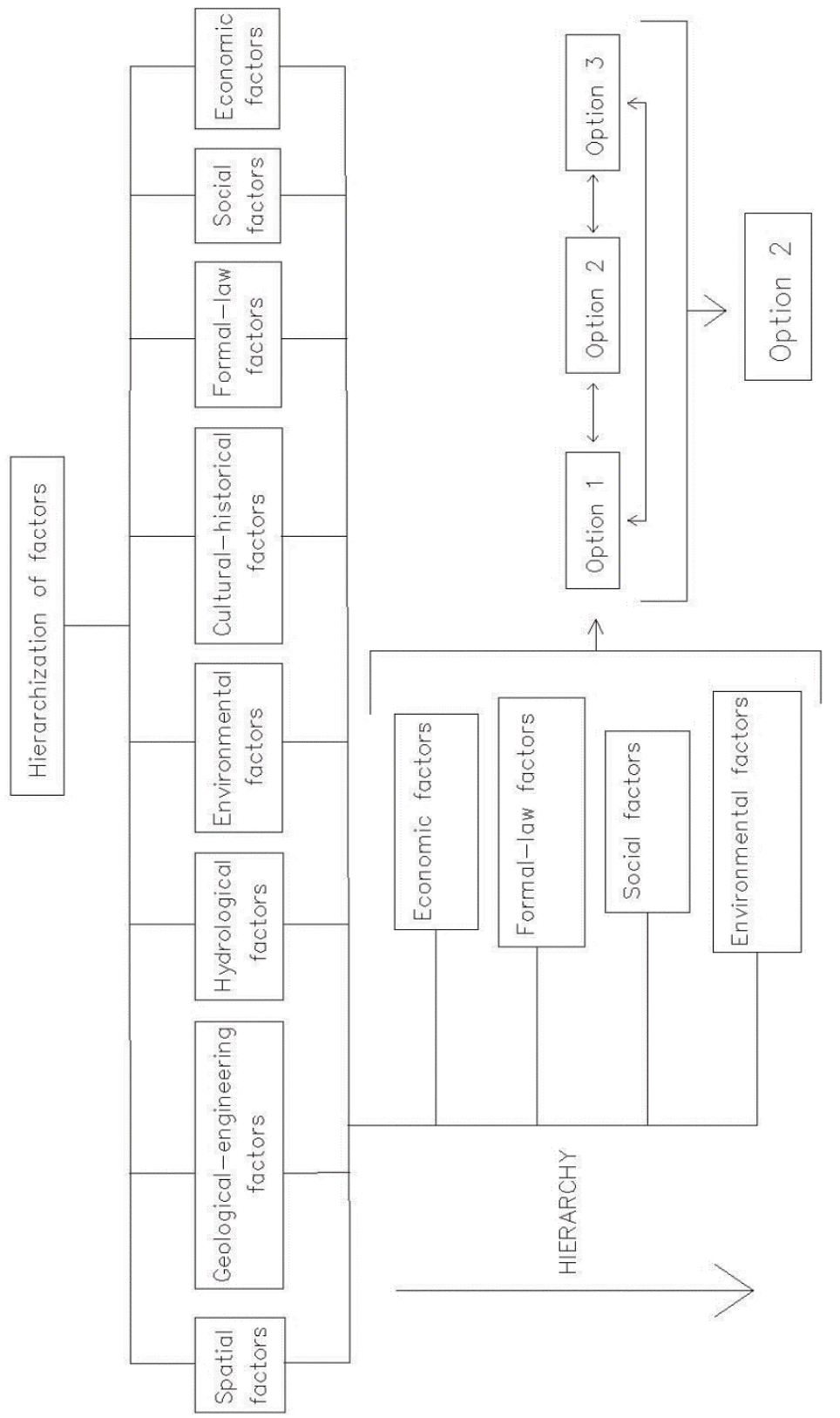

Fig. 3. The use of elements of AHP method to select the optimal concept.

Water direction - water-retaining for the excavation, forest-landscape for the areas around the excavation and business-service for the area of processing facilities, warehouses and administration buildings seems to best meet basic postulates of the process of 
reclamation, as this direction will improve the state of environment, influence positively on economic growth and will bring back spatial order as well as will significantly improve the quality of life of local community. What is more there is a possibility of protection of industrial heritage in the form of machines and mining devices, through compassing them into business park. Such activity will allow underling character, identity and history of the place whole adapting it to new, socially and economically useful functions at the same time.

\section{The concept of the reclamation of dolomite quarry in Siewierz}

The new function of the quarry and the surrounding lands assumes creation of the servicebusiness park with business incubators directed toward development and innovation with keeping minding-industrial tradition and identity. All the buildings of the current mine will be adapted and adjusted to the needs of modern business. Apart from the office buildings there will be training and conference rooms. There will also be a possibility of locating research center cooperating with the industry and business. Joining the science and business as well as creation of good and friendly environment for the development of new companies will filly use significant potential of this place. What is more, such type of investment in the place of past quarry will perfectly write into the trend of the region's development with strong accent on industrial and mining tradition which in Silesia is strongly advertised. The area of the mine including the surroundings of the excavation was divided into four zones mutually dependent and interlocking, as shown in the figure 4.

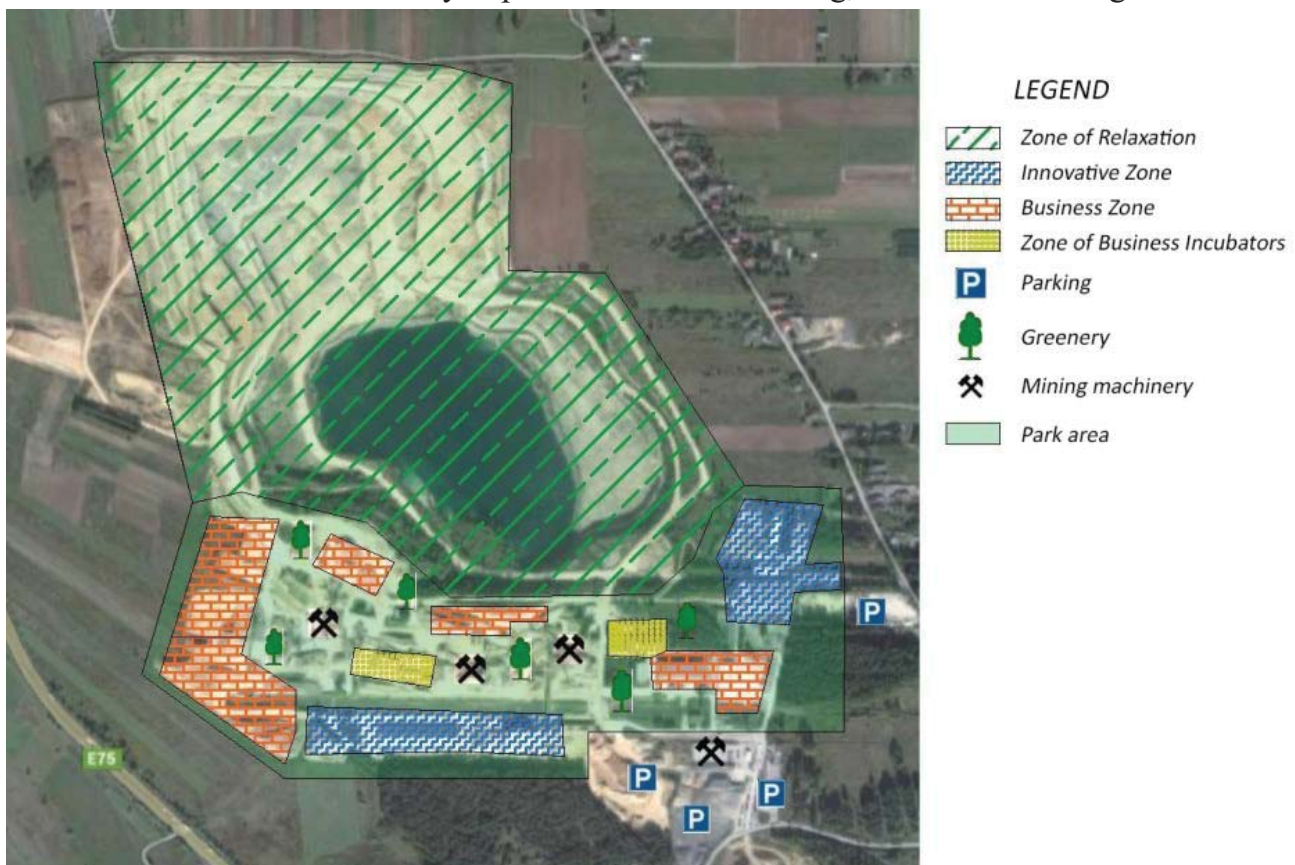

Fig. 4. Development of the quarry area.

All the zones were designed depending on its function, it is necessary to mention the connection thanks to which they are to complete each other. Moreover, they were composed into park, which is a mutual place unifying particular zones. Zone of relaxation surrounds the excavation and is located on the areas destined for greenery. Because of forest-landscape direction of reclamation of those lands there is not much plans for building 
recreational infrastructure. This zone from the side of excavation will be fenced and protected by wooden barriers, matching the forest surroundings. There will be path planned and at the points of the biggest landscape value there will be some benches. The zone is created with the thought of business park workers who will be able to breathe in fresh air and clam down during their break and inspire by surrounding nature. Moreover, this zone will be arranged in such way so its landscape value will be visible from the office windows what will make the work more pleasant and create friendly working environment. It will be possible thanks to the layer growing i.e. from the building side lower and medium-height greenery is designed and gradually way from the buildings it will move to higher greenery. Essential element of the landscape will be water-retaining reservoir created in the excavation therefore it is important not to cover it with trees and plants. On the area of the whole zone and surrounding areas there will be a silence rule, not to scare animals and keep forest character of the place. Innovation zone is destined for research centers and centers cooperating with universities which will provide qualified staff and transfer of knowledge and with companies which will show needs and practical demand for innovative solutions and technologies. In this zone it will be possible to locate various kinds of laboratories and server rooms as well as auditorium and interactive training rooms, thanks to what it will be possible to exchange knowledge of various levels. Location of Innovative Zone is to provide easy access to it for new firms from business incubators and huge companies from business zone. Business zone are facilities designed for businesses with strong position in the market. There are office facilities as well as such which can be adapted for other purposes, according to needs of the given company. Buildings of this zone are located in four places creating with the buildings of innovative zone the frame of the area where currently administration buildings and processing facilities are located. Buildings located closer to the excavation will be smaller comparing to those in the south of the complex. Such step is to keep spatial order and providing access to green landscape also from the office windows not located directly next to excavation and forest area. The Zone Of Business Incubators are objects designed for young business and small developing firms, which according to idea of business incubators will be provided with support and help of specialists from various fields in making first steps in the market. In the offices of the Zone variously-sized offices will be located, so as to young businessman could rent space adjusted to their needs. There will also be rooms of coworking type where it will be possible to rent a desk with the access to office devices and fast internet. Those facilities are located between the buildings of Business and Innovation Zones, with the aim of cooperation and integration and kind of care over developing business.

Between the buildings of the zones mining machines which remained after the quarry activity will be arranged into the space for keep the memory of history of the place before reclamation. One of the machines will be also located by the entry parking. Such objects are to relate to the past and identity. Moreover, between buildings and machines it is planned to introduce lower greenery and singular trees, which will complete the landscape.

The space between the zones is planned as car free, therefore all parking area at the main entrance from the south side and one by the Innovative Zone on the east part of the area. There will be a map of the complex on each parking making it easy to know where to go. The area of the business park will be space which symbolizes development and unlimited possibilities and freedom of activity. Important element will be putting accent on to integration with nature and relation to mining tradition. It is to be friendly and pro creativity place. 


\section{Summary}

Revitalization of post-industrial areas, including post mining is a very important issue. Quite often huge potential in post-industrial areas is wasted. Therefore, revitalization process is crucial, which may be a chance of regaining old greatness through giving new, socially, environmentally and economical useful functions. The whole area of the dolomite quarry in Siewierz was divided into functional zones. Such step allows to use all benefits and values of diverse space as well as will meet the demands of local spatial planning documents.

Analysis of external and internal conditions showed possibilities and potential as well as restrictions of the described area. On this base three possibilities of future redevelopment of quarry came up. During analytical hierarchical process, the most important criteria of choosing optimal direction of reclamation - economic and formal-law factor - were emerged. Comparison of particular redevelopment possibilities with regard to factors hierarchy showed that the best concept is to be service-business direction with waterretaining development of the excavation and forestry development of the area directly neighboring with it.

Such multidirectional way of revitalization of Górnicze Zakłady Dolomitowe S.A. brings with itself a chance for economic and social growth of Siewierz borough and creating it into modern business-science and people -friendly place and also it will improve the state of the environment as well as creation of spatial order. Multidirectional revitalization will therefore guarantee a synergy effect. Moreover, realizing the reclamation project of the quarry, one may think of the usage of wasteland located in the neighborhood creating complex and integrated program of revitalization of neighboring boroughs which thanks to improving its attractiveness could influence creation of new and worthy point of the Silesian conurbation map.

\section{References}

1. Z. Kasztelewicz, M. Ptak, Mining Sience, 132, 165-175 (2011)

2. Z. Kassztelewicz, S. Hajdo, S. Sypniowski, Problemy Ekologii, 14, 22-32 (2010)

3. A. Ostręga, Sposoby zagospodarowania wyrobisk $i$ terenów po eksploatacji złóż surowców węglanowych na przykładzie Krzemionek Podgórskich w Krakowie (2004)

4. R. Krzysztofik, Encyklopedia Województwa Ślaskiego (2014)

5. Plan ruchu odkrywkowego zakładu górniczego (2015)

6. Projekt Zagospodarowania Złoża dolomitów triasowych $i$ dewońskich „BRUDZOWICE” (2015)

7. Raport o oddziaływaniu na środowisko dla przedsięwzięcia: „Odkrywkowa eksploatacja dolomitów triasowych i dewońskich ze złoża „Brudzowice” (2012)

8. Uchwała Nr XX/158/2000 Rady Miejskiej w Siewierzu z dnia 25 kwietnia 2000r. w sprawie: studium uwarunkowań i kierunków zagospodarowania przestrzennego gminy Siewierz (2000)

9. Uchwała Nr XXVIII/206/2004 Rady Miejskiej w Siewierzu z dnia 30 września 2004r. W sprawie: miejscowego planu zagospodarowania przestrzennego dla terenu górniczego kopalni dolomitu ze złoża "Brudzowice" oraz terenu przyległego w Gminie Siewierz (2004)

10. https://www.siewierz.pl

11. Statystyczne Vademecum Samorzadowca (2015) 